\title{
Article \\ Development of Nickel- and Magnetite-Promoted Carbonized Cellulose Bead-Supported Bimetallic Pd-Pt Catalysts for Hydrogenation of Chlorate Ions in Aqueous Solution
}

\author{
Emóke Sikora ${ }^{1,2}$, Dániel Koncz-Horváth ${ }^{2}$, Gábor Muránszky ${ }^{1,2}$, Ferenc Kristály ${ }^{3}$, Béla Fiser ${ }^{1,2,4}$, \\ Béla Viskolcz ${ }^{1}$ (D) and László Vanyorek ${ }^{1, *}$ \\ 1 Institute of Chemistry, University of Miskolc, 3515 Miskolc-Egyetemváros, Hungary; \\ kemsik@uni-miskolc.hu (E.S.); kemmug@uni-miskolc.hu (G.M.); kemfiser@uni-miskolc.hu (B.F.); \\ bela.viskolcz@uni-miskolc.hu (B.V.) \\ 2 Higher Education Industry Cooperation Centre, University of Miskolc, \\ 3515 Miskolc-Egyetemváros, Hungary; femkhd@uni-miskolc.hu \\ 3 Institute of Mineralogy and Geology, University of Miskolc, 3515 Miskolc-Egyetemváros, Hungary; \\ askkf@uni-miskolc.hu \\ 4 Ferenc Rákóczi II, Transcarpathian Hungarian College of Higher Education, 90200 Beregszász, Ukraine \\ * Correspondence: kemvanyi@uni-miskolc.hu
}

Citation: Sikora, E.; Koncz-Horváth, D.; Muránszky, G.; Kristály, F.; Fiser, B.; Viskolcz, B.; Vanyorek, L. Development of Nickel- and Magnetite-Promoted Carbonized Cellulose Bead-Supported Bimetallic Pd-Pt Catalysts for Hydrogenation of Chlorate Ions in Aqueous Solution. Int. J. Mol. Sci. 2021, 22, 11846. https://doi.org/10.3390/ ijms222111846

Academic Editor: Andrea Salis

Received: 4 October 2021

Accepted: 29 October 2021

Published: 31 October 2021

Publisher's Note: MDPI stays neutral with regard to jurisdictional claims in published maps and institutional affiliations.

Copyright: (c) 2021 by the authors. Licensee MDPI, Basel, Switzerland. This article is an open access article distributed under the terms and conditions of the Creative Commons Attribution (CC BY) license (https:/ / creativecommons.org/licenses/by/ $4.0 /)$.

\begin{abstract}
Cellulose grains were carbonized and applied as catalyst supports for nickel- and magnetitepromoted bimetallic palladium- and platinum-containing catalysts. The bimetallic spherical aggregates of $\mathrm{Pd}$ and $\mathrm{Pt}$ particles were created to enhance the synergistic effect among the precious metals during catalytic processes. As a first step, the cellulose bead-based supports were impregnated by nitrate salts of nickel and iron and carbonized at $973 \mathrm{~K}$. After this step, the nickel was in an elemental state, while the iron was in a magnetite form in the corresponding supports. Then, Pd and Pt particles were deposited onto the supports and the catalyst surface; precious metal nanoparticles (10-20 nm) were clustered inside spherical aggregated particles 500-600 nm in size. The final bimetallic catalysts (i.e., $\mathrm{Pd}-\mathrm{Pt} / \mathrm{CCB}, \mathrm{Pd}-\mathrm{Pt} / \mathrm{Ni}-\mathrm{CCB}$, and $\mathrm{Pd}-\mathrm{Pt} / \mathrm{Fe}_{3} \mathrm{O}_{4}-\mathrm{CCB}$ ) were tested in hydrogenation of chlorate ions in the aqueous phase. For the nickel-promoted Pd-Pt catalyst, a $>99 \%$ chlorate conversion was reached after $45 \mathrm{~min}$ at $80{ }^{\circ} \mathrm{C}$. In contrast, the magnetite-promoted sample reached an $84.6 \%$ chlorate conversion after $3 \mathrm{~h}$. Reuse tests were also carried out with the catalysts, and in the case of $\mathrm{Pd}-\mathrm{Pt} / \mathrm{Ni}-\mathrm{CCB}$ after five cycles, the catalytic activity only decreased by $\sim 7 \%$ which proves the stability of the system.
\end{abstract}

Keywords: Pd-Pt clusters; chlorate reduction; magnetite

\section{Introduction}

The elimination of chlorate $\left(\mathrm{ClO}_{3}^{-}\right)$from industrial process water is necessary not only from an environmental but also from an industrial point of view [1-4]. In the field of chlor-alkali electrolysis, the first membranes were introduced in the 1970s, which provided a more efficient ion-selective space-separation than the previously used diaphragm [5]. The two main disadvantages of the process that includes a membrane cell are the formation of chlorate and the sensitivity of the applied membranes to impurities [6]. During chlor-alkali electrolysis, the chlorate-contaminated brine has a negative effect on the quality of caustic soda and could also damage the membranes and decrease the efficiency of the procedure [3]. One solution to reduce the chlorate concentration is catalytic hydrogenation $[1,3,7]$. The main advantage of this procedure-compared to the currently used thermal hydrochloric acid treatment-is that small amounts of additional chemicals are enough to achieve the desired effect $[4,8]$.

However, membranes are extremely sensitive not only to chlorate but also to other elements, especially to metals such as $\mathrm{Ca}, \mathrm{Mg}$, and $\mathrm{Al}$ [9]. This should also be considered in 
the selection of the applied catalytic system in order to minimize the input of contaminants into the technology. It is also important to use a catalyst with a macroscopic structure, since the separation of finely divided powder from materials for the medium is difficult $[10,11]$. Therefore, easily separable support materials must be used to avoid this issue.

Carbon materials are extremely popular supports not only in catalysis but also in many other fields due to the fact of their electrical conductivity, chemical resistance, relatively high specific surface area, and, in some cases, good separation [12,13]. As a renewable resource, cellulose is preferred as a starting material to prepare functional carbon materials [14]. Therefore cellulose and carbonized cellulose (CC) have already been successfully tested in various applications, where they have been used as a microwave absorber [15], flexible electrode [16], anode for high-performance lithium ion batteries [17], and catalyst support [18]. Carbon-supported platinum group metal ( $\mathrm{Pd}, \mathrm{Pt}, \mathrm{Ru}, \mathrm{Ir}$, and $\mathrm{Rh})$ catalysts showed outstanding results in chlorate reduction [19-21]. Several studies have confirmed that catalysts made by combining these precious metals, such as bimetallic Pd-Pt systems, generally perform better than their monometallic counterparts due to the synergistic effects [22-25].

By studying hydrodesulfurization reactions, it was found that hydrogenation was faster with Pd-containing catalysts compared to their Pt-containing counterparts due to the higher hydrogenation ability of palladium, but Pt catalyst had a higher desulfurization activity [26]. Furthermore, bimetallic catalyst was also synthesized and tested, and it was more active than expected from a simple combination of the monometallic $\mathrm{Pd}$ and $\mathrm{Pt}$ systems because of the chemical synergism between the noble metals [26]. Guerrero et al. came to a similar conclusion when they found that the activity of their Pd-Pt catalyst was twice as active as the corresponding monometallic Pt catalyst on an Al2O3-TiO2 support [27]. This synergistic effect was studied in the case of a USY zeolite-supported $\mathrm{Pd}-\mathrm{Pt}$ catalyst, and a new bond was found that was completely different from the Pt-Pt and $\mathrm{Pt}-\mathrm{Pd}$ metallic bonds. It has been established that in this catalyst, where the ratio of $\mathrm{Pd}: \mathrm{Pt}$ is $4: 1$, this new bond reflects the ionic properties of Pt through the Pt-Pd interaction, and the bond has a cationic and sulfur tolerance property [28]. The synergistic effect was exploited by Sangmoon Byun et al. when they synthesized Pd-Pt-Fe3O4 nanoparticles [29]. This combined and magnetic catalyst has proven to be extremely durable (300 reuse tests) and has shown effective results in the reduction of nitro compounds to anilines or alkylamines. This durability could also be attributed to the combination of the two metals, as some studies have confirmed that supported Pd-Pt catalysts are more resistant to catalyst poisons such as sulfur $[28,30]$.

In this study, cellulose grains were carbonized and applied as catalyst support for nickeland magnetite-promoted palladium-platinum catalysts. The developed bimetallic catalysts were tested in chlorate hydrogenation in the aqueous phase to prove their applicability.

\section{Results and Discussion}

\subsection{Characterization of the Catalyst Supports}

Thermogravimetric analysis was carried out on the impregnated and non-impregnated samples to monitor the cellulose carbonization process (Supplementary Materials Figure S1). The first weight loss occurred at approximately $375 \mathrm{~K}$ due to the evaporation of water. The subsequent large weight losses in the case of the iron nitrate, nickel nitrate-containing, and non-impregnated samples were $25.9 \mathrm{wt} \%, 22.3 \mathrm{wt} \%$, and $19.2 \mathrm{wt} \%$, respectively, which can be associated with the oxidation of carbon.

SEM images of the various CCBs shows that the surfaces of the Ni-CCBs were more homogenously covered with metal nanoparticles compared to the magnetite-containing beads (Supplementary Materials Figure S2A,D). In this sense, the dispersibility of nickel particles on the support was more homogenous.

The surface of the carbonized, magnetite-containing beads was richly coated with magnetite nanoparticles (Figure 1A). The crystallites were aggregated, and the particle sizes were large $(7-10 \mu \mathrm{m})$, but smaller structures $(1-2 \mu \mathrm{m}$ and even $10-40 \mathrm{~nm})$ were also 
visible on the surface (Supplementary Materials Figure S2). The size distribution in this sense was very inhomogeneous for the $\mathrm{Fe}_{3} \mathrm{O}_{4}-\mathrm{CCB}$ sample.
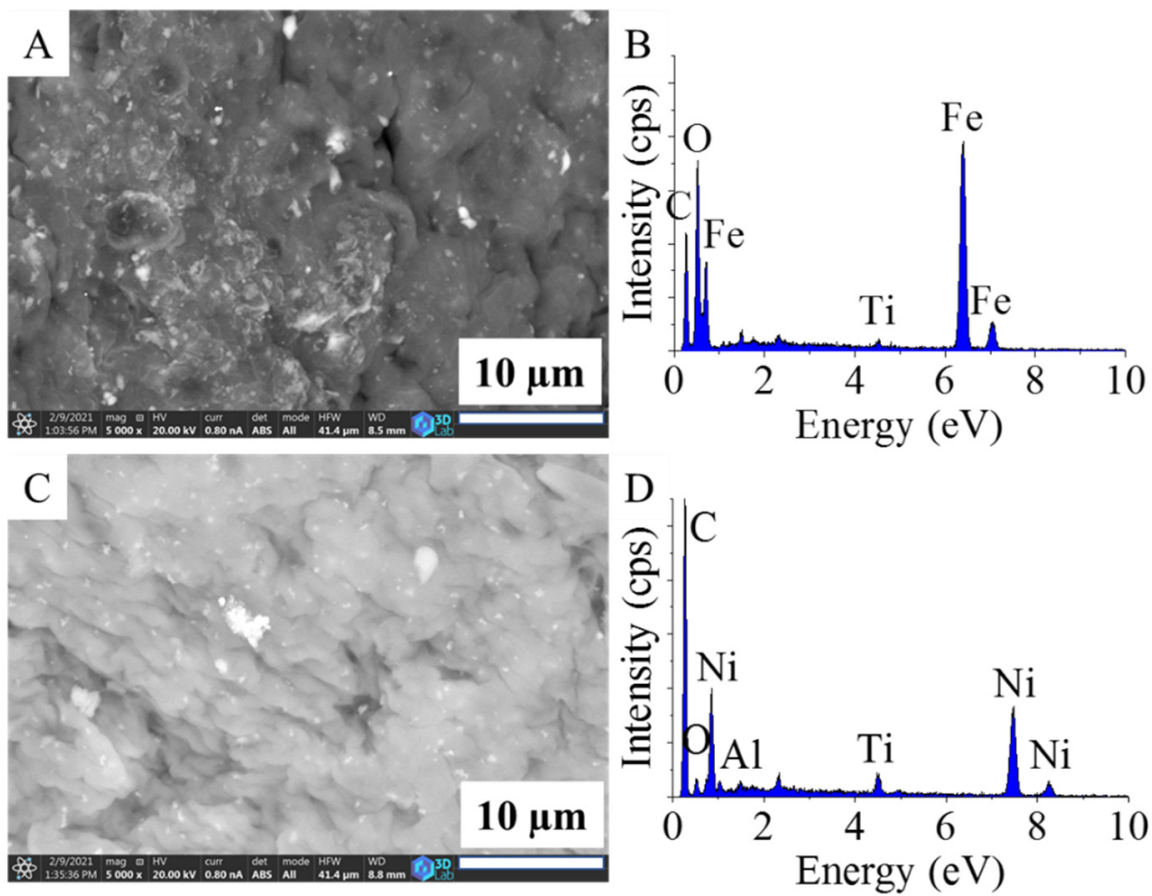

Figure 1. SEM images and EDS spectra of the $\mathrm{Fe}_{3} \mathrm{O}_{4}-\mathrm{CCB}(\mathbf{A}, \mathbf{B})$ and $\mathrm{Ni}-\mathrm{CCB}(\mathbf{C}, \mathbf{D})$ catalyst supports.

For the nickel-containing support, the size distribution of the Ni particles on the surface of the CCBs covered a wide range, from a few hundred nanometers to 10-20 microns (Figure $1 \mathrm{C}$ and Supplementary Materials Figure S2E,F).

The non-impregnated CCBs were also analyzed by SEM (Supplementary Materials Figure S3). Interestingly, fluffy, coral-like surfaces with small fibrous formations were found, which formed during the decomposition of cellulose. However, this was not experienced in the case of the impregnated samples, and it is assumed that the presence of metal nitrates led to the oxidation of these formations.

The EDS spectrum of $\mathrm{Fe}_{3} \mathrm{O}_{4}-\mathrm{CCB}$ verified the presence of oxygen and iron which originated from the magnetite (Figure 1B). Titanium was also detected in the carbon matrix, which indicates the presence of $\mathrm{TiO}_{2}$ and can be explained by the synthesis protocol of the Mavicell cellulose beads [31].

The presence of nickel in Ni-CCB was confirmed (Figure 1D). Titanium was detected in this case as well and, in addition, $\mathrm{Al}$ was also found, which can be associated with the sample holder of the SEM. There was also a smaller but visible peak of oxygen, which indicates that oxygen-containing functional groups were also present in the sample. To identify these functional groups, FTIR measurements were conducted.

On the FTIR spectrum of the non-impregnated CCB sample, several oxygen containing functional groups were identified (Figure 2A). At the $3454 \mathrm{~cm}^{-1}$ wavenumber, a peak was located that was associated with the stretching vibration mode of the hydroxyl groups. The bending mode of hydroxyl groups $(\beta \mathrm{OH})$ was also identified at $1392 \mathrm{~cm}^{-1}$.

The presence of other oxygen-containing functional groups was verified, as two more peaks at $1228 \mathrm{~cm}^{-1}$ and $1058 \mathrm{~cm}^{-1}$ were located on the infrared spectrum of the carbon beads that corresponded to the stretching vibration mode of the $\mathrm{C}-\mathrm{O}-\mathrm{C}$ and the $\mathrm{C}-\mathrm{O}$ bonds. Furthermore, the presence of surface carboxyl functional groups $(v \mathrm{COOH})$ was also proved (Figure 2A, $1734 \mathrm{~cm}^{-1}$ ). The band at $1590 \mathrm{~cm}^{-1}$ can be linked to $v \mathrm{C}=\mathrm{C}$ which represents the skeletal vibration of the carbon matrix. The symmetric $\left(2924 \mathrm{~cm}^{-1}\right)$ and asymmetric $\left(2855 \mathrm{~cm}^{-1}\right)$ vibration modes of the $\mathrm{CH}_{2}$ groups were also located in two well separated bands. The identified oxygen-containing functional groups contributed to the 
hydrophilic character of the carbonized cellulose beads and improved their wettability in the aqueous phase. The carboxyl and hydroxyl groups can be deprotonated in the aqueous phase which will lead to negative electrokinetic potential. Thus, the negatively charged surface of the beads and the metal cations can establish electrostatic interactions. In this sense, these groups are beneficial and capable of anchoring the metal ions and, thus, play a role in the catalyst preparation processes. After carbonization, the intensity of the peaks on the spectra of the nickel(II) nitrate- and iron(III) nitrate-impregnated cellulose beads was smaller compared to the non-impregnated CCBs. A metal-oxygen vibration mode was also identified between the 500 and $700 \mathrm{~cm}^{-1}$ wavenumbers. In the $\mathrm{Fe}_{3} \mathrm{O}_{4}-\mathrm{CCB}$ sample, the wide $\mathrm{vOH}$ band also included a hydroxyl bond of magnetite and adsorbed water. The band of the $v C=C$ vibration showed a shift in the case of the nickel- and magnetite-containing carbon samples, which suggests the formation of $\pi$ backdonation $(\pi-\mathrm{d})$ interaction between the metal (and metal oxide) particles and carbon beads.

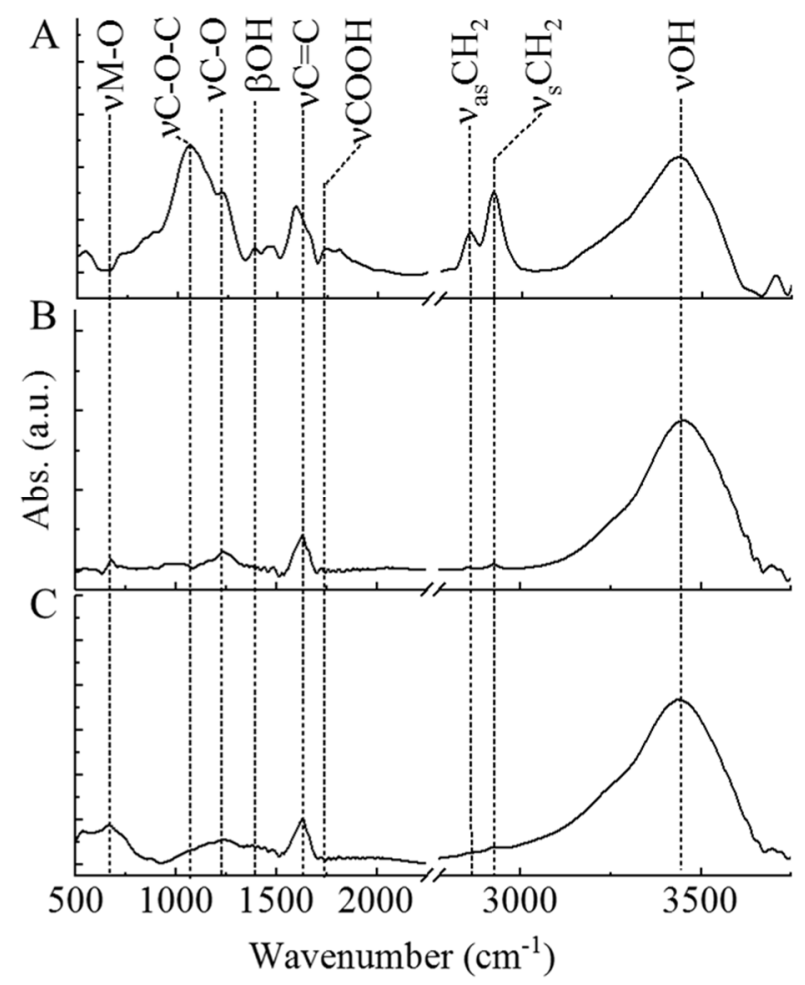

Figure 2. FTIR spectra of the non-impregnated (A), $\mathrm{Ni}$ - (B), and $\mathrm{Fe}_{3} \mathrm{O}_{4}$-containing (C) carbonized cellulose beads (CCBs).

The carbon supports were also examined by XRD (Figure 3). On the diffractogram of the nickel-containing carbon beads, peaks were identified at $44.5^{\circ}$ and $51.8^{\circ}$, two theta degrees, which were associated with the $\mathrm{Ni}(111)$ and $\mathrm{Ni}(200)$ reflexions of elemental nickel (JCPDS Card No. 04-0850). Anatase reflexions were also identified at $25.3^{\circ}(101), 36.9^{\circ}(103)$, $37.8^{\circ}(004), 38.5^{\circ}(112), 48.0^{\circ}(200), 53.9^{\circ}(105), 55.0^{\circ}(211)$, and $62.7^{\circ}(204)$, two theta degrees (JCPDS Card No. 21-1272). The presence of anatase can be explained by the production of the Mavicell beads. The 002 reflexion of carbon is shown at $21.1^{\circ}$, two theta degrees (JCPSD Card. No. 41-1487).

The XRD pattern of the $\mathrm{Fe}_{3} \mathrm{O}_{4}-\mathrm{CCB}$ sample confirmed that the iron was in the magnetite $\left(\mathrm{Fe}_{3} \mathrm{O}_{4}\right)$ form (Figure 3B). Peaks at $18.3^{\circ}, 30.1^{\circ}, 35.4^{\circ}, 43.1^{\circ}, 57.1^{\circ}$, and $62.7^{\circ}$, two theta degrees, were associated with the (111), (220), (311) (400), (511), and (440) reflexions of synthetic magnetite. Reflexions corresponding to anatase and the wide peak (002) of carbon were identified on the diffractogram of this sample as well. 

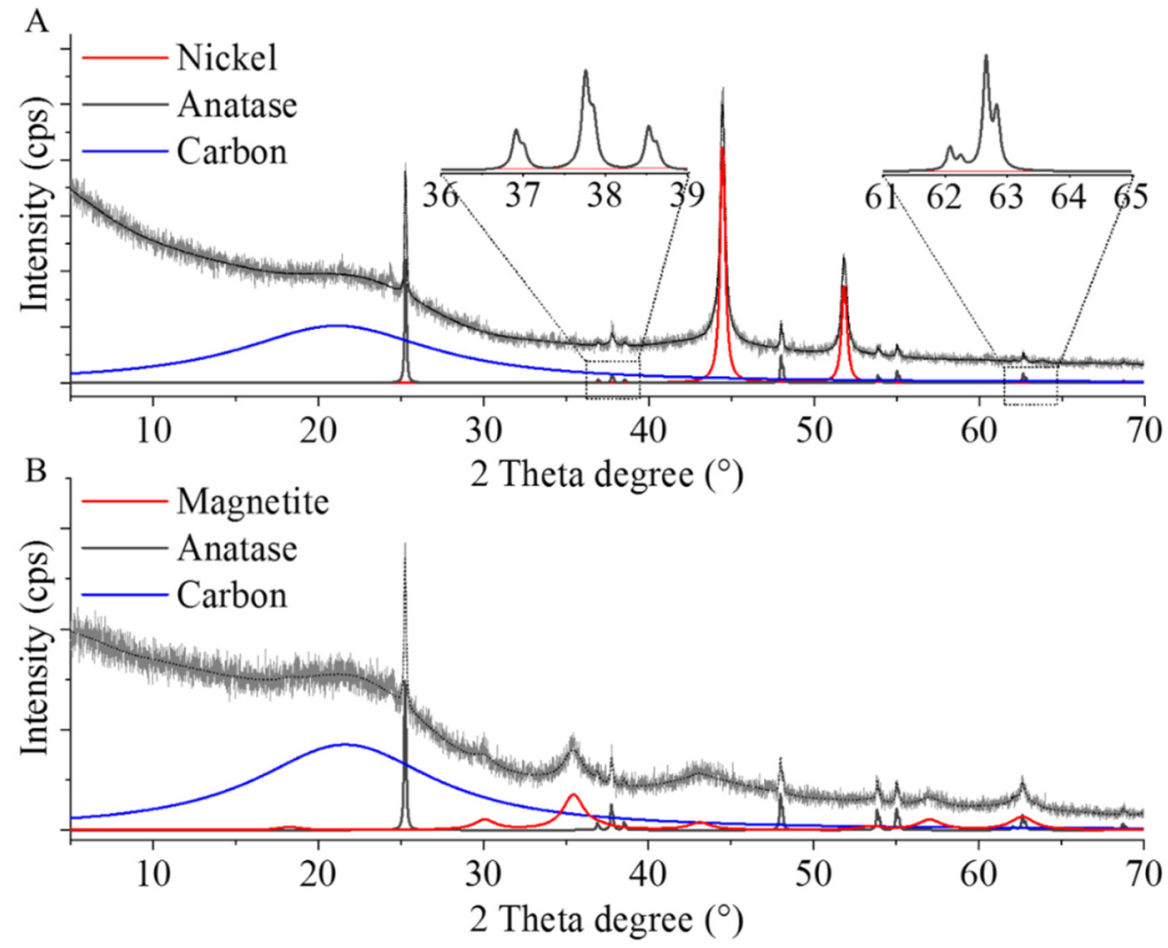

Figure 3. XRD patterns of the $\mathrm{Ni}$ - $(\mathbf{A})$ and magnetite $\left(\mathrm{Fe}_{3} \mathrm{O}_{4}\right)$-containing $(\mathbf{B})$ carbonized cellulose supports.

\subsection{Characterization of the $\mathrm{Pd}-\mathrm{Pt} / \mathrm{CCB}, \mathrm{Pd}-\mathrm{Pt} / \mathrm{Ni}-\mathrm{CCB}$, and $\mathrm{Pd}-\mathrm{Pt} / \mathrm{Fe}_{3} \mathrm{O}_{4}-\mathrm{CCB}$ Catalysts}

The surface area of the prepared catalysts were determined, and it was found that the $\mathrm{Pd}-\mathrm{Pt} / \mathrm{Ni}-\mathrm{CCB}$ sample had the highest $\left(431 \mathrm{~m}^{2} \cdot \mathrm{g}^{-1}\right)$, while the Pd-Pt/CCB sample had the lowest $\left(379 \mathrm{~m}^{2} \cdot \mathrm{g}^{-1}\right)$. The $\mathrm{Pd}-\mathrm{Pt} / \mathrm{Fe}_{3} \mathrm{O}_{4}-\mathrm{CCB}$ catalyst was right in between the other two samples in terms of surface area $\left(408 \mathrm{~m}^{2} \cdot \mathrm{g}^{-1}\right)$. The metal content of the final catalysts was measured using ICP-OES (Table 1).

Table 1. Metal contents of the prepared $\mathrm{Pd}-\mathrm{Pt} / \mathrm{CCB}, \mathrm{Pd}-\mathrm{Pt} / \mathrm{Ni}-\mathrm{CCB}$, and $\mathrm{Pd}-\mathrm{Pt} / \mathrm{Fe}_{3} \mathrm{O}_{4}-\mathrm{CCB}$ catalysts.

\begin{tabular}{ccccc}
\hline & $\mathbf{N i} \mathbf{( w t} \%)$ & $\mathbf{F e}_{\mathbf{3}} \mathbf{O}_{\mathbf{4}} \mathbf{( w \mathbf { t } \% )}$ & $\mathbf{P d} \mathbf{( w t} \mathbf{0})$ & $\mathbf{P t}(\mathbf{w t} \mathbf{o})$ \\
\hline $\mathrm{Pd}-\mathrm{Pt} / \mathrm{Ni}-\mathrm{CCB}$ & 8.97 & - & 2.03 & 0.29 \\
$\mathrm{Pd}-\mathrm{Pt} / \mathrm{Ni}-\mathrm{CCB}(5 \times$ used $)$ & 8.85 & - & 2.06 & 0.29 \\
$\mathrm{Pd}-\mathrm{Pt} / \mathrm{Fe}_{3} \mathrm{O}_{4}-\mathrm{CCB}$ & - & 6.27 & 1.71 & 0.34 \\
$\mathrm{Pd}-\mathrm{Pt} / \mathrm{Fe}_{3} \mathrm{O}_{4}-\mathrm{CCB}(5 \times$ used $)$ & - & 6.48 & 1.72 & 0.35 \\
$\mathrm{Pd}-\mathrm{Pt} / \mathrm{CCB}$ & - & - & 0.96 & 0.19 \\
$\mathrm{Pd}-\mathrm{Pt} / \mathrm{CCB}(5 \times$ used $)$ & - & - & 0.95 & 0.18 \\
\hline
\end{tabular}

Based on the results, the $\mathrm{Ni}-\mathrm{CCB}$ and $\mathrm{Fe}_{3} \mathrm{O}_{4}-\mathrm{CCB}$ were able to bind more precious metals than the metal-free $\mathrm{CCB}$ support. Measurements were also performed after reuse tests $(5 \times)$ of the catalysts and, in most cases, the metal content remained the same as before; thus, no significant metal leaching occurred (Table 1).

In one of our previous studies [32], non-carbonized cellulose beads were used for chlorate hydrogenation. The non-carbonized samples had low specific surface area $\left(<1 \mathrm{~m}^{2} / \mathrm{g}\right)$ and low precious metal content $(<0.6 \mathrm{wt} \%)$, and the $\mathrm{Pd}-\mathrm{Pt} / \mathrm{CB}$ catalyst achieved only a $72 \%$ chlorate conversion. Furthermore, metal leaching from the surface occurred. In contrast to the non-carbonized catalyst, the carbonized samples had a larger specific surface area $\left(\sim 400 \mathrm{~m}^{2} / \mathrm{g}\right)$, and the carrier-active metal interaction was stronger, as leaching did not occur.

The Pd-Pt/CCB catalyst was examined via SEM, and on the images, nanoparticle aggregates with a $\sim 500 \mathrm{~nm}$ size were identified (Figure $4 \mathrm{~A}, \mathrm{~B}$ ). These spherical aggregates 
contained palladium and platinum particles together according to the elemental mapping (Supplementary Materials Figure S4). By the EDS analysis of the catalyst, the presence of palladium and platinum as catalytically active components and other elements. such as carbon, oxygen, and titanium, were verified (Figure 4C).
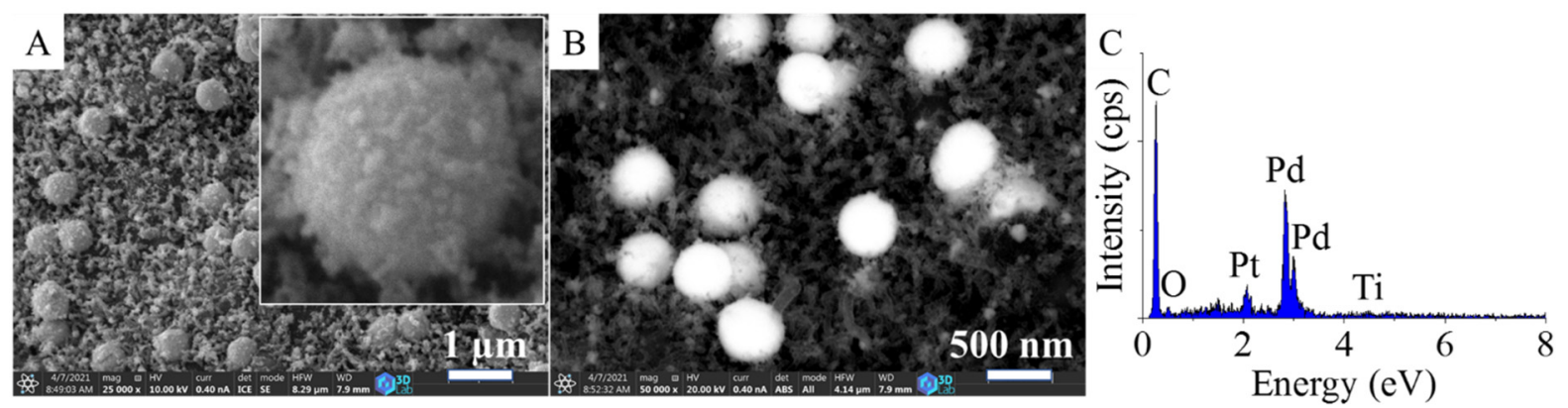

Figure 4. SEM images (A,B) and EDS spectrum (C) of the Pd-Pt/CCB catalyst.

The SEM analysis of the $\mathrm{Pd}-\mathrm{Pt} / \mathrm{Fe}_{3} \mathrm{O}_{4}-\mathrm{CCB}$ catalyst shows that aggregates formed on the surface in this case as well (Figure 5A). The EDS spectrum verified the presence of catalytically active metals, platinum, and palladium (Figure 5B). Additional peaks were associated with carbon, oxygen, iron, and Ti. Aluminum also appeared on the spectrum due to the sample holder of the SEM.
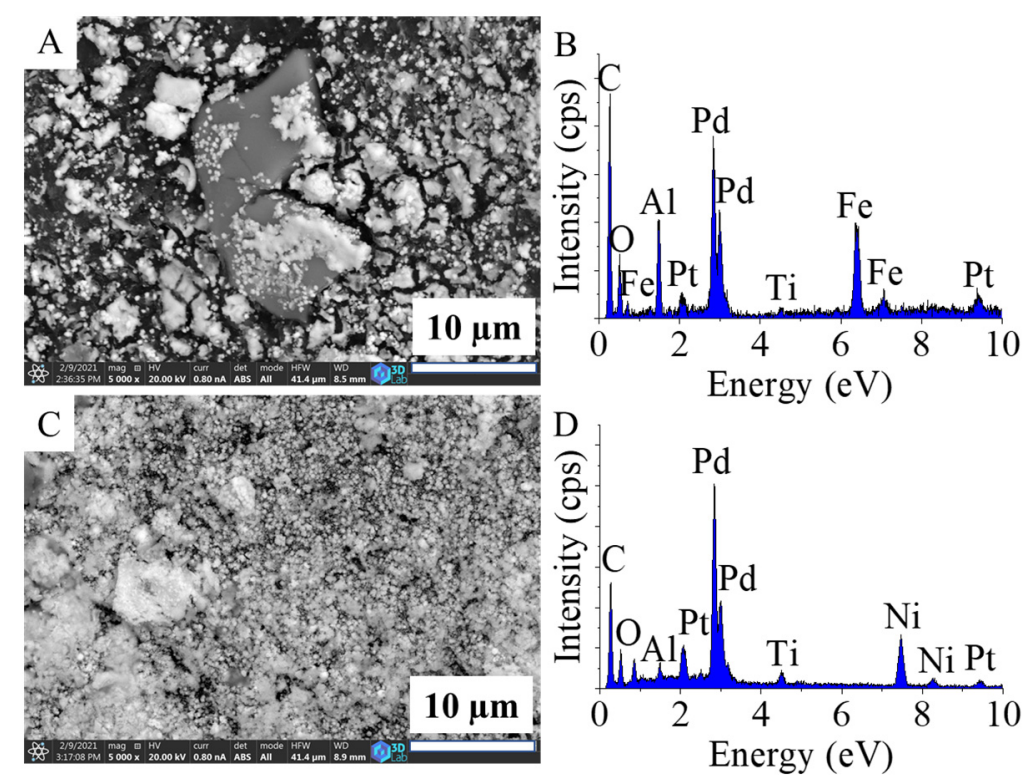

Figure 5. SEM images and EDS spectra of the $\mathrm{Pd}-\mathrm{Pt} / \mathrm{Fe}_{3} \mathrm{O}_{4}-\mathrm{CCB}(\mathbf{A}, \mathbf{B})$ and $\mathrm{Pd}-\mathrm{Pt} / \mathrm{Ni}-\mathrm{CCB}(\mathbf{C}, \mathbf{D})$ catalysts.

The Pd-Pt/Ni-CCB catalyst was also analyzed by SEM and, as in the case of the other two catalysts, metal particle aggregates were located on the surface (Figure 5C). The size of these aggregates were smaller compared to the ones on the surface of the $\mathrm{Pd}-\mathrm{Pt} / \mathrm{Fe}_{3} \mathrm{O}_{4}-$ CCB catalyst. The presence of palladium, platinum, and nickel was confirmed by the EDS analysis (Figure 5D).

By increasing the magnification, it can be seen that the size of the spherical crystals of the precious metals were in the range of $\sim 500-700 \mathrm{~nm}$, and these larger aggregates were based on smaller nanoparticles of 10-20 nm (Supplementary Materials Figure S5). This special structure occurred for both Ni- and magnetite-promoted catalysts. The surface morphology of the $\mathrm{Pd}-\mathrm{Pt}$ aggregates significantly differed from each other for the $\mathrm{Pd}-$ $\mathrm{Pt} / \mathrm{Fe}_{3} \mathrm{O}_{4}-\mathrm{CCB}$ and $\mathrm{Pd}-\mathrm{Pt} / \mathrm{Ni}-\mathrm{CCB}$ samples (Supplementary Materials Figure S5B,D). The precious metal spheres had a more closed, denser structure for the $\mathrm{Pd}-\mathrm{Pt} / \mathrm{Fe}_{3} \mathrm{O}_{4}-\mathrm{CCB}$ 
(Supplementary Materials Figure S5B) sample and a looser, more open structure in the case of Pd-Pt/Ni-CCB (Supplementary Materials Figure S4D). Furthermore, the size of the individual $\mathrm{Pt}$ and $\mathrm{Pd}$ nanoparticles of the aggregates were larger in the magnetitecontaining sample compared to the nickel-promoted catalyst (Supplementary Materials Figure S5). The structural difference of the Pd-Pt crystallites cannot be explained by the type of precursor salts of the promoter metals, because in both cases nitrate salts were applied. However, the nickel was in elemental form, while the iron was in oxide form (as magnetite). As the magnetite and nickel particles on the surface of the CCB were in ideal places for crystal growth, they had an influence on the speed of nucleation and, thus, the structure of the crystallites, which build-up spherical aggregates in the catalysts.

XRD measurement were also carried out to characterize the developed catalysts. On the diffractogram of the $\mathrm{Pd}-\mathrm{Pt} / \mathrm{CCB}$, reflexions of elemental palladium were identified at $40.1^{\circ}(111), 46.5^{\circ}(200)$, and $68.1^{\circ}$ (220), two theta degrees (JCPSD Card. No. 46-1043) (Figure 6A). The reflexions of $\mathrm{Pt}(111)$ and $\mathrm{Pt}(200)$ were also located at $39.4^{\circ}$ and $45.9^{\circ}$ $2 \theta$ degrees (JCPSD Card. No. 87-0640). On the diffractograms of the Pd-Pt/Ni-CCB and $\mathrm{Pd}-\mathrm{Pt} / \mathrm{Fe}_{3} \mathrm{O}_{4}-\mathrm{CCB}$ catalysts, the presence of palladium and platinum was verified (Figure $6 \mathrm{~B}, \mathrm{C}$ ). Anatase was also identified in each catalyst, and the presence of nickel and magnetite was confirmed based on the corresponding XRD patterns (Figure 6B,C).
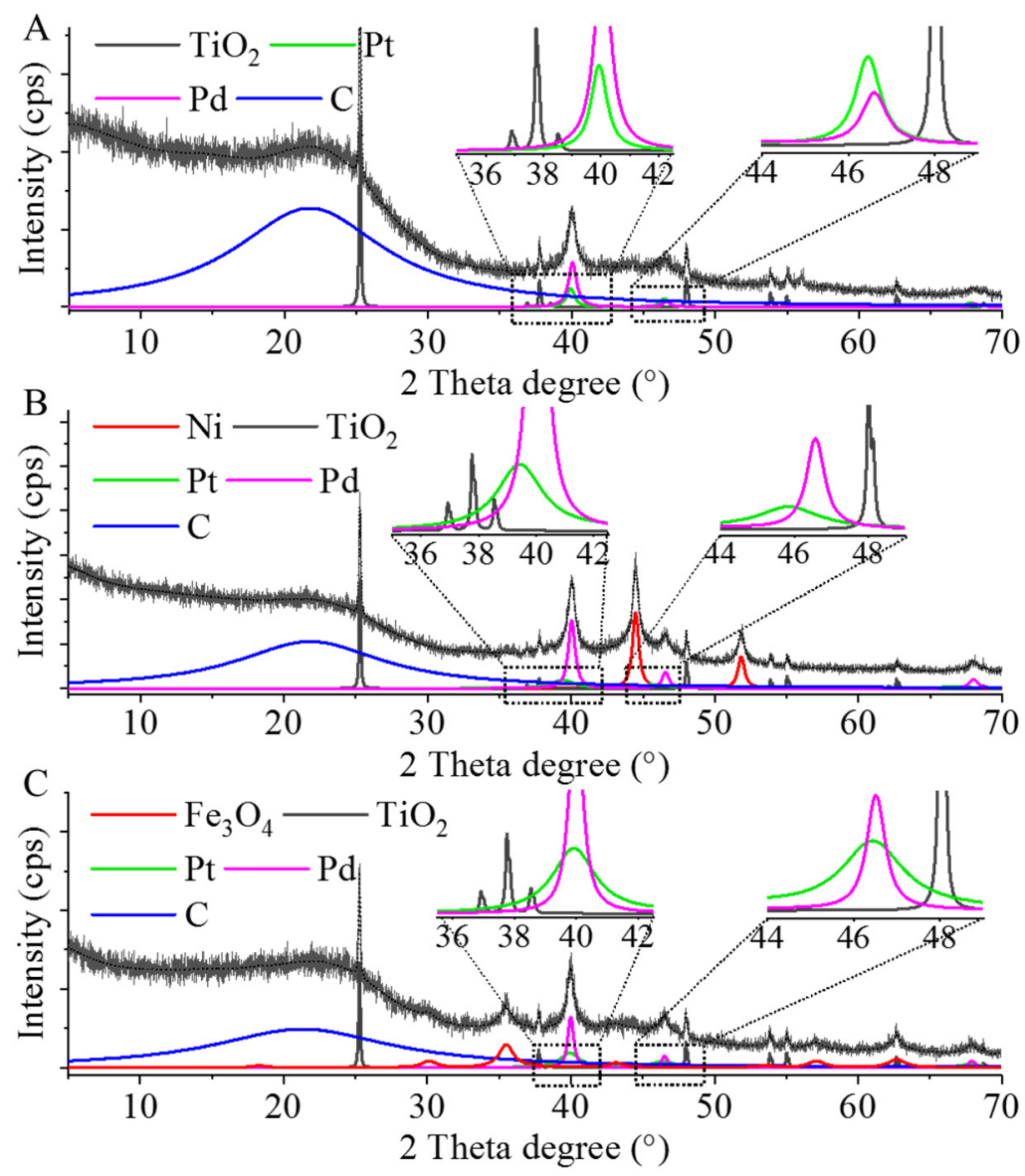

Figure 6. XRD patterns of the $\mathrm{Pd}-\mathrm{Pt} / \mathrm{CCB}(\mathbf{A}), \mathrm{Pd}-\mathrm{Pt} / \mathrm{Ni}-\mathrm{CCB}(\mathbf{B})$, and $\mathrm{Pd}-\mathrm{Pt} / \mathrm{Fe}_{3} \mathrm{O}_{4}-\mathrm{CCB}(\mathbf{C})$ catalysts.

XRD measurements confirmed that palladium and platinum were present as individual nanoparticles in the catalysts, and they did not form an alloy. However, based on the results of the EDS mapping of the spherical aggregates (Supplementary Materials Figure S5), palladium and platinum nanoparticles were together in both catalysts (Figure 7). 


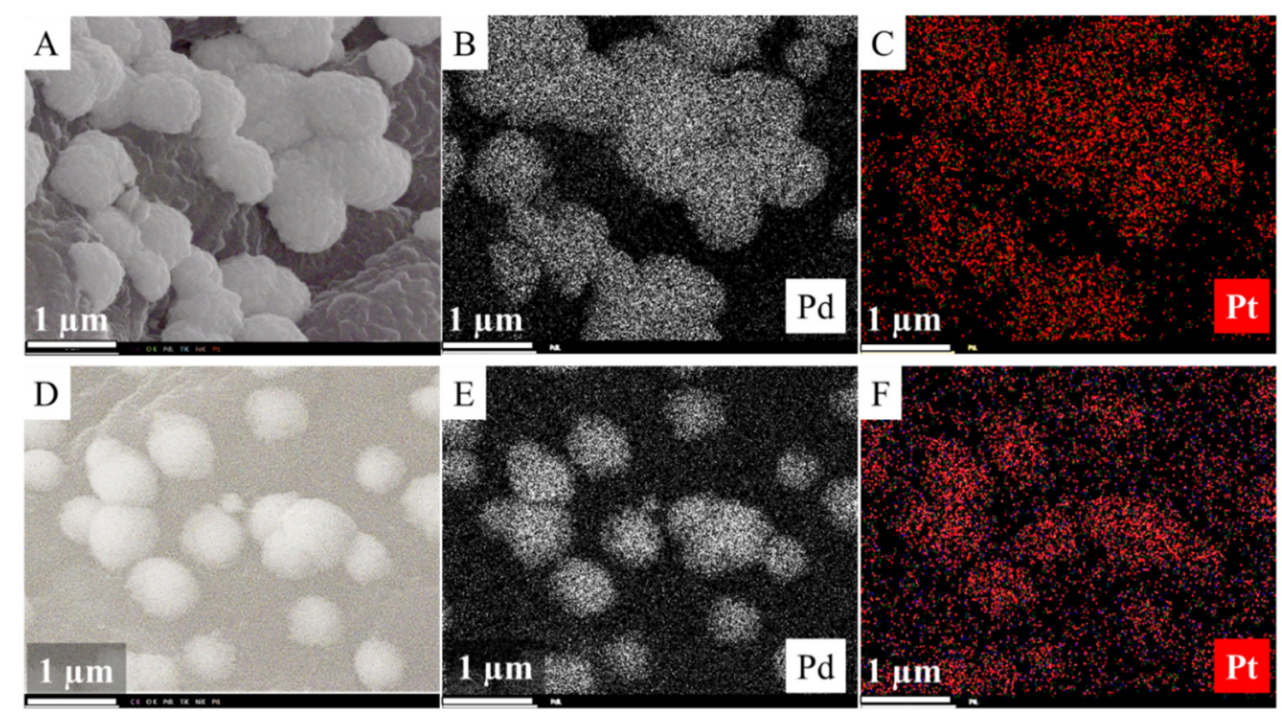

Figure 7. Elemental maps of the $\mathrm{Pd}-\mathrm{Pt} / \mathrm{Fe}_{3} \mathrm{O}_{4}-\mathrm{CCB}(\mathrm{A}-\mathrm{C})$ and $\mathrm{Pd}-\mathrm{Pt} / \mathrm{Ni}-\mathrm{CCB}(\mathbf{D}-\mathbf{F})$ catalysts.

FTIR measurements were performed after reuse tests of the $\mathrm{Pd}-\mathrm{Pt} / \mathrm{CCB}, \mathrm{Pd}-\mathrm{Pt} / \mathrm{Ni}-$ $\mathrm{CCB}$, and $\mathrm{Pd}-\mathrm{Pt} / \mathrm{Fe}_{3} \mathrm{O}_{4}-\mathrm{CCB}$ catalysts (Supplementary Materials Figure S6). Significant differences were not visible between the FTIR spectra of the catalysts before and after use in the case of the $\mathrm{Pd}-\mathrm{Pt} / \mathrm{Ni}-\mathrm{CCB}$ and $\mathrm{Pd}-\mathrm{Pt} / \mathrm{Fe}_{3} \mathrm{O}_{4}-\mathrm{CCB}$ catalysts (Figure 2BC, Supplementary Materials Figure S6B,C). However, for the used $\mathrm{Pd}-\mathrm{Pt} / \mathrm{CCB}$ catalyst, the peaks representing the oxygen-containing functional groups $(\nu C-O-C, v C-O$, and $\beta \mathrm{OH})$ significantly decreased (Supplementary Materials Figure S6A). Moreover, the $-\mathrm{CH}_{2}$ bands decreased compared to the carbonized cellulose beads.

The catalysts after reuse tests were also examined by XRD (Supplementary Materials Figures S7-S9). The XRD patterns of the fresh and used catalysts were compared. For the $\mathrm{Pd}-\mathrm{Pt} / \mathrm{CCB}$ and $\mathrm{Pd}-\mathrm{Pt} / \mathrm{Fe}_{3} \mathrm{O}_{4}-\mathrm{CCB}$ catalysts, there were no changes in the patterns before and after the reuse tests (Supplementary Materials Figures S7 and S8). However, in the case of the $\mathrm{Pd}-\mathrm{Pt} / \mathrm{Ni}-\mathrm{CCB}$ catalyst, transformations occurred after the catalytic tests, and new phases formed including $\mathrm{PdO}, \mathrm{PtO}_{2}$, and $\mathrm{NiCO}_{3}$ in small amounts (Supplementary Materials Figure S9). Small amounts of the noble metals were oxidized by the chlorate (as an oxidizing agent) and, thus, $\mathrm{PdO}$ and $\mathrm{PtO}_{2}$ formed. The presence of nickel carbonate can be explained by the formation of nickel oxide during the catalytic tests, which further transformed to $\mathrm{NiCO}_{3}$ by reacting with the $\mathrm{CO}_{2}$ content of the air during drying.

\subsection{Catalytic Hydrogenation of Chlorate Ions in Aqueous Solution}

The catalytic activity of the nickel- and magnetite-containing catalyst supports were measured (Supplementary Materials Figure S10). Both samples were active, but only a low conversion $\left(\mathrm{Fe}_{3} \mathrm{O}_{4}-\mathrm{CCB} 17.7 \mathrm{n} / \mathrm{n} \%\right.$ and $\left.\mathrm{Ni}-\mathrm{CCB} 42.4 \mathrm{n} / \mathrm{n} \%\right)$ was achieved.

The three developed catalysts, $\mathrm{Pd}-\mathrm{Pt} / \mathrm{CCB}, \mathrm{Pd}-\mathrm{Pt} / \mathrm{Ni}-\mathrm{CCB}$, and $\mathrm{Pd}-\mathrm{Pt} / \mathrm{Fe}_{3} \mathrm{O}_{4}-\mathrm{CCB}$, were compared in hydrogenation of $\mathrm{ClO}_{3}{ }^{-}$ions (Supplementary Materials Figure S11). The $\mathrm{Pd}-\mathrm{Pt} / \mathrm{Ni}-\mathrm{CCB}$ sample was found to be the most catalytically active $\left(\mathrm{X}_{\mathrm{KClO}_{3}}>99 \mathrm{n} / \mathrm{n} \%\right.$ after $45 \mathrm{~min}$ at $353 \mathrm{~K}$ ) (Supplementary Materials Figure S11). Almost complete conversion was reached with the $\mathrm{Pd}-\mathrm{Pt} / \mathrm{CCB}$ catalyst, but more time was required $(\sim 3 \mathrm{~h})$, while with the $\mathrm{Pd}-\mathrm{Pt} / \mathrm{Fe}_{3} \mathrm{O}_{4}-\mathrm{CCB}$, only $84.6 \mathrm{n} / \mathrm{n} \%$ was achieved after $3 \mathrm{~h}$.

The enhanced catalytic activity of the nickel-promoted system can be explained by the structure of the Pd-Pt aggregates (Figure 4 and Supplementary Materials Figure S5). In case of the Ni-containing catalyst, the structure of the Pd-Pt crystals was opened, compared to the $\mathrm{Pd}-\mathrm{Pt} / \mathrm{Fe}_{3} \mathrm{O}_{4}-\mathrm{CCB}$ sample (Supplementary Materials Figure S5B,D). The structure of the aggregates in the $\mathrm{Pd}-\mathrm{Pt} / \mathrm{Ni}-\mathrm{CCB}$ catalyst contained smaller, spherical precious metal nanoparticles that were easily accessible for the reactant molecules in the hydrogenation process. Thus, with the Ni-promoted sample, the $\mathrm{H}_{2}$ activation was 
facilitated, and a higher catalytic activity was achieved compared to the promoter-free or magnetite-containing sample.

The stability of the catalysts was also studied and compared by applying reuse tests (Figure 8). The nickel-promoted catalyst showed the highest chlorate conversion after five cycles; moreover, the difference in the chlorate conversion between the first and fifth cycles was only $6.2 \%$. High conversion was achieved even though there was no regeneration (just a rinse and dry) between cycles (Figure $8 \mathrm{~A}, \mathrm{~B}$ ). In the case of the $\mathrm{Pd}-\mathrm{Pt} / \mathrm{Fe}_{3} \mathrm{O}_{4}-\mathrm{CCB}$ catalyst, deterioration was observed in the catalytic activity, as the chlorate conversion fell almost $14 \%$ during the 5 th cycle (Figure $8 \mathrm{C}, \mathrm{D}$ ). An even more significant decrease in the chlorate conversion $(24.5 \%$ ) was observed for the Pd-Pt/CCB catalyst (Figure 8E,F).

A

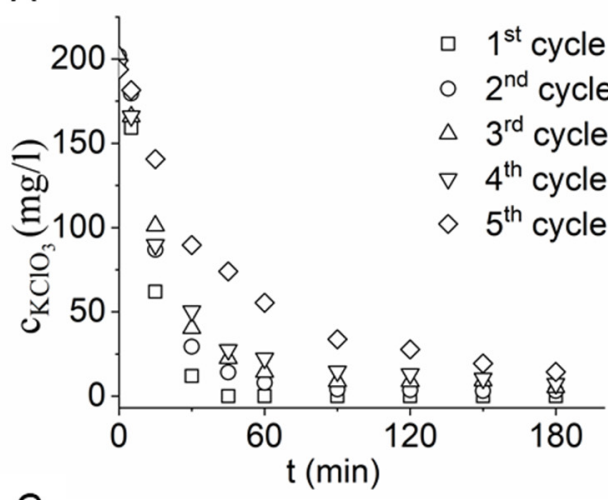

C

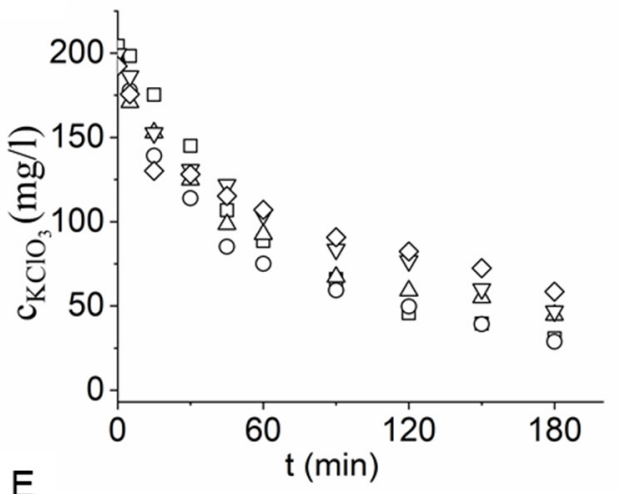

E

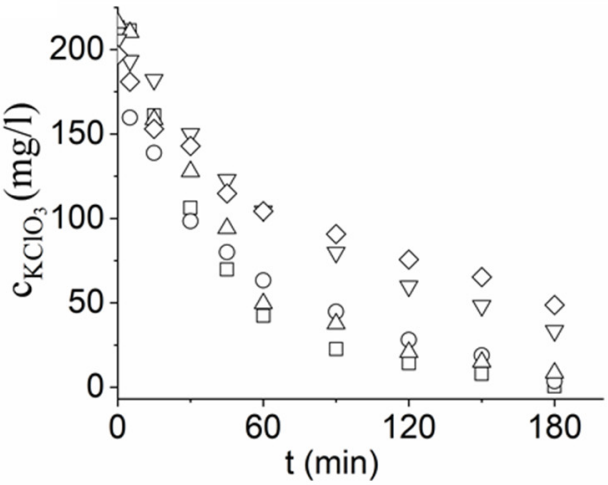

B
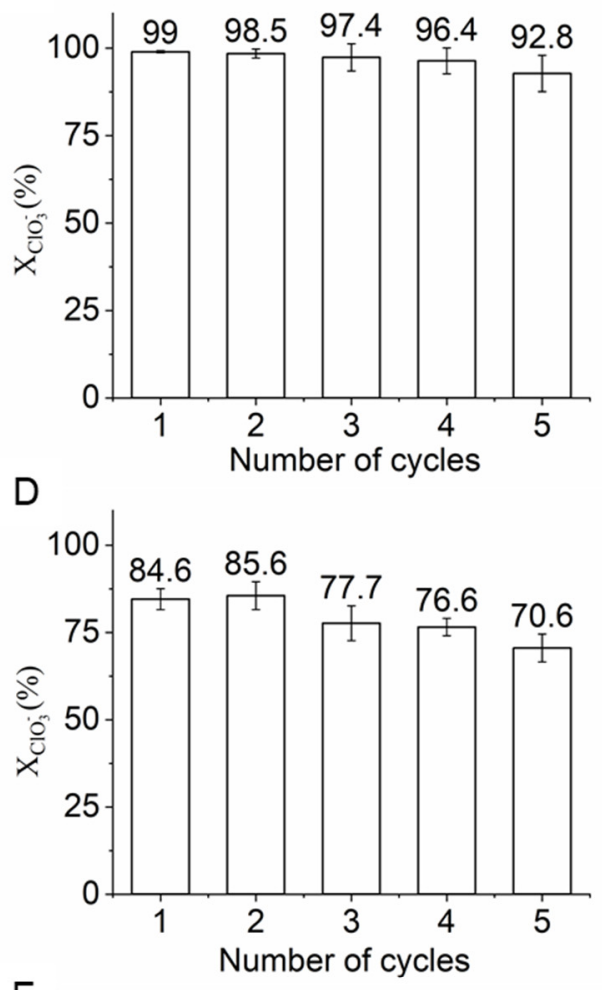

$\mathrm{F}$

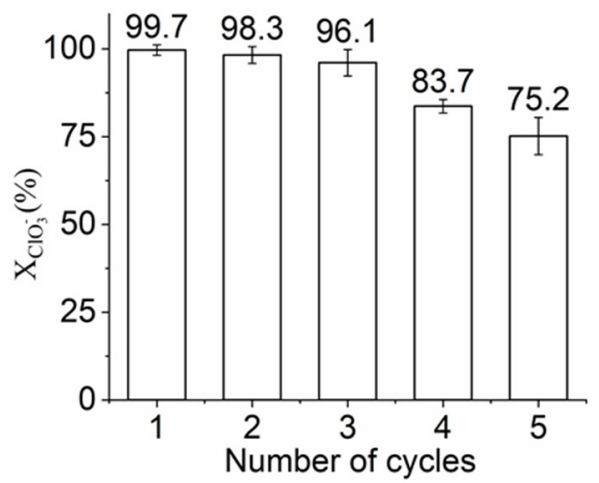

Figure 8. Chlorate conversion vs. time of hydrogenation using the $\mathrm{Pd}-\mathrm{Pt} / \mathrm{Ni}-\mathrm{CCB}(\mathrm{A}), \mathrm{Pd}-\mathrm{Pt} / \mathrm{Fe}_{3} \mathrm{O}_{4}{ }^{-}$ $\mathrm{CCB}(\mathrm{C})$, and $\mathrm{Pd}-\mathrm{Pt} / \mathrm{CCB}(\mathrm{E})$ catalysts. The chlorate conversion maximum after each reuse test cycle was determined for the $\mathrm{Pd}-\mathrm{Pt} / \mathrm{Ni}-\mathrm{CCB}(\mathbf{B}), \mathrm{Pd}-\mathrm{Pt} / \mathrm{Fe}_{3} \mathrm{O}_{4}-\mathrm{CCB}(\mathbf{D})$, and $\mathrm{Pd}-\mathrm{Pt} / \mathrm{CCB}(\mathrm{F})$ catalysts.

The rate constants of the chlorate hydrogenation reactions when the developed $\mathrm{Pd}-$ $\mathrm{Pt} / \mathrm{Ni}-\mathrm{CCB}, \mathrm{Pd}-\mathrm{Pt} / \mathrm{Fe}_{3} \mathrm{O}_{4}$, and $\mathrm{Pd}-\mathrm{Pt} / \mathrm{CCB}$ catalysts were applied were calculated using linear regression (Supplementary Materials Figure S12). The $k$ values were also determined for the reuse tests (Table 2, Supplementary Materials Figure S13). The reaction rate during 
the reuse tests slightly decreased from $2.5 \times 10^{-4} \mathrm{~s}^{-1}$ to $1.6 \times 10^{-4} \mathrm{~s}^{-1}$ after five cycles in the case of the $\mathrm{Pd}-\mathrm{Pt} / \mathrm{Fe}_{3} \mathrm{O}_{4}-\mathrm{CCB}$ catalyst (Table 2). For the nickel-promoted catalyst, a more significant decrease was observed in the reaction rate, whereas the initial $k$ value decreased from $1.6 \times 10^{-3} \mathrm{~s}^{-1}$ to $3.7 \times 10^{-4} \mathrm{~s}^{-1}$ after five cycles. The reaction rate also decreased when the Pd-Pt/CCB catalyst was applied. It must be noted that despite the decrease in the reaction rate, the $\mathrm{Pd}-\mathrm{Pt} / \mathrm{Ni}-\mathrm{CCB}$ catalyst was able to remove $>90 \%$ of the chlorate, even in the 5 th cycle.

Table 2. Reaction rate $(k)$ constants after the reuse tests.

\begin{tabular}{cccc}
\hline $\mathbf{k}\left(\mathbf{s}^{-1}\right)$ & $\mathbf{P d}-\mathbf{P t} / \mathbf{N i}-\mathbf{C C B}$ & $\mathbf{P d}-\mathbf{P t} / \mathbf{F e}_{3} \mathbf{O}_{\mathbf{4}}-\mathbf{C C B}$ & $\mathbf{P d - P t / C C B}$ \\
\hline 1st cycle & $1.6 \times 10^{-3} \pm 1.2 \times 10^{-4}$ & $2.5 \times 10^{-4} \pm 1.3 \times 10^{-5}$ & $4.2 \times 10^{-4} \pm 2.3 \times 10^{-5}$ \\
2nd cycle & $9.5 \times 10^{-4} \pm 5.5 \times 10^{-5}$ & $2.7 \times 10^{-4} \pm 1.8 \times 10^{-5}$ & $3.4 \times 10^{-4} \pm 1.9 \times 10^{-5}$ \\
3rd cycle & $7.7 \times 10^{-4} \pm 4.3 \times 10^{-5}$ & $2.2 \times 10^{-4} \pm 1.7 \times 10^{-5}$ & $3.1 \times 10^{-4} \pm 2.8 \times 10^{-5}$ \\
4th cycle & $6.3 \times 10^{-4} \pm 5.5 \times 10^{-5}$ & $1.8 \times 10^{-4} \pm 1.7 \times 10^{-5}$ & $1.7 \times 10^{-4} \pm 5.3 \times 10^{-6}$ \\
5th cycle & $3.7 \times 10^{-4} \pm 2.2 \times 10^{-5}$ & $1.6 \times 10^{-4} \pm 1.8 \times 10^{-5}$ & $1.3 \times 10^{-4} \pm 1.0 \times 10^{-5}$ \\
\hline
\end{tabular}

The catalysts were examined after the reuse tests, and chlorine was not detected in the samples (Supplementary Materials Figure S13). A simple wash and dry method was enough to reach a chlorine-free state of the catalysts, which were ready for reuse.

Thus, according to the results, the developed $\mathrm{Pd}-\mathrm{Pt} / \mathrm{Ni}-\mathrm{CCB}, \mathrm{Pd}-\mathrm{Pt} / \mathrm{Fe}_{3} \mathrm{O}_{4}$, and $\mathrm{Pd}-\mathrm{Pt} / \mathrm{CCB}$ catalysts are reusable, stable systems which can be applied efficiently in the hydrogenation of chlorate.

\section{Materials and Methods}

\subsection{Materials}

Mavicell (Hungarian Viscosa Corp., Nyergesújfalu, HU) was used to create carbonized cellulose beads (CCBs). Nickel(II) nitrate hexahydrate $\left(\mathrm{Ni}\left(\mathrm{NO}_{3}\right)_{2} \cdot 6 \mathrm{H}_{2} \mathrm{O}\right.$, Sigma-Aldrich Corp., Steinheim am Albuch, Germany) and iron(III) nitrate nonahydrate $\left(\mathrm{Fe}\left(\mathrm{NO}_{3}\right)_{3} \cdot 9 \mathrm{H}_{2} \mathrm{O}\right.$, Merck Chemicals $\mathrm{GmbH}$, Darmstadt, DE) were used as precursors of nickel and magnetite. Palladium(II) nitrate dihydrate $\left(\mathrm{Pd}\left(\mathrm{NO}_{3}\right)_{2} \cdot 2 \mathrm{H}_{2} \mathrm{O}\right.$, Alfa Aesar, Ltd., Heysham, UK) and platinum(IV) chloride ( $\mathrm{PtCl}_{4}$, Sigma-Aldrich, Corp., Steinheim am Albuch, Germany) were used as precursors of the $\mathrm{Pd}$ and $\mathrm{Pt}$ nanoparticles. Potassium chlorate $\left(\mathrm{KClO}_{3}\right.$, Reanal Ltd., Budapest, Hungary), potassium iodide (KI, VWR Ltd., Radnor, PA, USA), and sulfuric acid $\left(\mathrm{H}_{2} \mathrm{SO}_{4}\right.$, VWR Ltd., Radnor, PA, USA) were used during the chlorate hydrogenation experiments.

\subsection{Catalyst Preparation}

Mavicell cellulose beads (5-5 g) were impregnated with an aqueous solution of nickel(II) nitrate and iron(III) nitrate. After drying (at $378.15 \mathrm{~K}$ ), the impregnated beads were carbonized in a nitrogen atmosphere at $973.15 \mathrm{~K}$. Non-impregnated cellulose beads were also carbonized for use as a reference. The impregnated and non-impregnated carbonized cellulose beads (CCBs) $(1.14 \mathrm{~g})$ were added to $50.00 \mathrm{~mL}$ aqueous solution of $0.10 \mathrm{~g}$ palladium(II) nitrate dihydrate and $0.011 \mathrm{~g}$ anhydrous platinum(IV) chloride. The precious metal ions were reduced to the elemental state using $50 \mathrm{~mL}$ hydrazine hydrate $(4.00 \mathrm{wt} \%)$. Thus, three different catalysts, $\mathrm{Pd}-\mathrm{Pt} / \mathrm{CCB}, \mathrm{Pd}-\mathrm{Pt} / \mathrm{Ni}-\mathrm{CCB}$, and $\mathrm{Pd}-\mathrm{Pt} / \mathrm{Fe}_{3} \mathrm{O}_{4}-\mathrm{CCB}$, were prepared and dried at $378.15 \mathrm{~K}$ overnight.

\subsection{Characterization Techniques}

The particle size and morphology of the catalysts were studied using a Helios G4 PFIB CXe Plasma Focused Ion Beam Scanning Electron Microscope (PFIB-SEM) equipped with an EDAX Octane Elect EDS System with APEX Analysis Software using carbon tape for sample preparation. EDS maps were created with a $1024 \times 800$ resolution, and 1 frame was recorded with a $1000 \mu$ s collecting time. X-ray diffraction (XRD) analysis was also performed using a Bruker D8 Advance diffractometer $(\mathrm{Cu}-\mathrm{K} \alpha$ source, $40 \mathrm{kV}$, and $40 \mathrm{~mA}$ 
with a Vantec 1 detector) to identify the nanoparticles. Thermogravimetric measurements were performed using a TG 209 F3 Tarsus with a $10 \mathrm{~K} / \mathrm{min}$ heating rate starting from $308 \mathrm{~K}$ and increasing to $973.15 \mathrm{~K}$ in a nitrogen atmosphere. The functional groups of the carbonized cellulose beads were examined by Fourier transform infrared spectroscopy (FTIR) using Bruker Vertex 70 equipment. Measurements were carried out in transmission mode with $\mathrm{KBr}$ pellets ( $10 \mathrm{mg}$ sample in $250 \mathrm{mg} \mathrm{KBr}$ ), and the interval was $400-4000 \mathrm{~cm}^{-1}$, while the resolution was $4 \mathrm{~cm}^{-1}$ with a $16 \mathrm{~min}^{-1}$ scan rate. The specific surface area of the catalysts was determined by $\mathrm{CO}_{2}$ adsorption-desorption measurements using Micromeritics ASAP 2020 equipment and applying the Dubinin-Radushkevich isotherm model. The metal contents of the catalysts were measured using a Varian 720 ES inductively coupled optical emission spectrometer (ICP-OES). For the ICP-EOS measurements, the samples were ignited after preparation by placing them into an aqua regia.

\subsection{Catalytic Hydrogenation of Chlorate}

Hydrogenation of the $\mathrm{ClO}_{3}{ }^{-}$ions was performed in an aqueous solution of potassiumchlorate $\left(200 \mathrm{mg} \cdot \mathrm{dm}^{-3}\right)$. The solution was placed in a side-inlet gas washing bottle with fritted disc, and the temperature was set to $80^{\circ} \mathrm{C}$ using a Julabo circulator. A gas supply was provided ( $40 \mathrm{sccm}$ nitrogen and $100 \mathrm{sccm}$ hydrogen), while the amount of catalyst was $200 \mathrm{mg}$ for each measurement. The experiments were carried out for $3 \mathrm{~h}$, and sampling was performed after $0,5,15,30,45,60,90,120,150$, and $180 \mathrm{~min}$. After the catalytic tests, the catalysts were washed with distilled water and dried at $105^{\circ} \mathrm{C}$ overnight.

Chlorate concentration in the samples was determined using the UV-6300PC spectrophotometer at a $351 \mathrm{~nm}$ wavelength. The following redox reaction between iodide and chlorate ions were considered during the measurements:

$$
\mathrm{KClO}_{3}+6 \mathrm{KI}+6 \mathrm{HCl} \rightarrow 3 \mathrm{H}_{2} \mathrm{O}+3 \mathrm{I}_{2}+7 \mathrm{KCl}
$$

Due to the iodine formation, the color intensity and, thus, the absorbance changed, which allowed for the determination of the chlorate concentration with appropriate calibration. Calibration was conducted using potassium-chlorate solutions with different concentrations $\left(0,50,100,150\right.$, and $\left.200 \mathrm{mg} \cdot \mathrm{dm}^{-3}\right)$. For each sample $(1 \mathrm{~mL}), 100 \mathrm{mg}$ potassium iodide and $1 \mathrm{~mL}$ hydrochloric acid were added, and then it was diluted to $50 \mathrm{~mL}$ with distilled water and measured with the spectrophotometer.

\section{Conclusions}

Catalysts were developed and carbonized cellulose beads were decorated with palladium-platinum nanoparticles using a chemical reduction method. Three different supports-pure CCBs and Ni- and magnetite-promoted CCBs-were synthesized and applied. They were decorated with $\mathrm{Pd}-\mathrm{Pt}$ nanoparticles using a catalyst preparation process that was simple and efficient, and within which it was not necessary to apply time- and energy-consuming activations steps. The simultaneous decomposition of the precursors led to the formation of larger $(500-600 \mathrm{~nm}$ ) spherical aggregates that contained $\mathrm{Pd}$ and $\mathrm{Pt}$ together. Due to the fact of these bimetallic aggregates, the synergistic effect of the precious metals was more pronounced during the catalytic processes. By the application of nickel and magnetite as promoters, the structure of the aggregates changed, and in the case of the $\mathrm{Pd}-\mathrm{Pt} / \mathrm{Ni}-\mathrm{CCB}$ catalyst, cavities formed on the surface. The Ni-CCB and $\mathrm{Fe}_{3} \mathrm{O}_{4}-\mathrm{CCB}$ supports were able to bind more precious metals than the metal-free CCB. Furthermore, the size of the individual Pt and Pd nanoparticles were smaller for the nickel-promoted catalyst. These were easily accessible for the reactant molecules in the hydrogenation process. Thus, with the Ni-promoted sample, the $\mathrm{H}_{2}$ activation was facilitated, and higher catalytic activity was achieved compared to the promoter-free or the magnetite-containing sample. By using the $\mathrm{Pd}-\mathrm{Pt} / \mathrm{Ni}-\mathrm{CCB}$ catalyst, $99 \mathrm{n} / \mathrm{n} \%$ chlorate conversion was reached after $45 \mathrm{~min}$ at $80^{\circ} \mathrm{C}$. For the $\mathrm{Pd}-\mathrm{Pt} / \mathrm{Fe}_{3} \mathrm{O}_{4}-\mathrm{CCB}$ catalyst, lower chlorate conversion $(84.6 \mathrm{n} / \mathrm{n} \%)$ was obtained after $3 \mathrm{~h}$. During the reuse tests, the catalytic activity of the nickel-promoted bimetallic catalyst slightly decreased, and the $\mathrm{ClO}_{3}{ }^{-}$conversion fell by only $\sim 6 \%$ after five cycles. In 
contrast, the catalytic activity of the promoter-free (Pd-Pt/CCB) and magnetite-promoted (Pd-Pt $/ \mathrm{Fe}_{3} \mathrm{O}_{4}-\mathrm{CCB}$ ) systems decreased by $24.5 \%$ and $~ 14 \%$, respectively. All in all, three catalysts were developed and successfully applied in chlorate hydrogenation. Although the $\mathrm{Pd}-\mathrm{Pt} / \mathrm{Ni}-\mathrm{CCB}$ system is the most promising, the other two are also applicable for chlorate reduction.

Supplementary Materials: They are available online at https://www.mdpi.com/article/10.3390/ ijms222111846/s1.

Author Contributions: Formal analysis, D.K.-H., G.M. and F.K.; Funding acquisition, B.V.; Investigation, E.S.; Supervision, L.V.; Visualization, E.S.; Writing-original draft, E.S.; Writing-review and editing, B.F. All authors have read and agreed to the published version of the manuscript.

Funding: This research was funded by the European Regional Development Fund, grant number the GINOP-2.3.4-15-2016-00004. The APC was funded by the University of Miskolc.

Institutional Review Board Statement: Not applicable.

Informed Consent Statement: Not applicable.

Data Availability Statement: Not applicable.

Acknowledgments: This study was prepared with the professional support of the Doctoral Student Scholarship Program of the Co-Operative Doctoral Program of the Ministry of Innovation and Technology financed by the National Research, Development, and Innovation Fund. This research was supported by the European Union and the Hungarian State, co-financed by the European Regional Development Fund in the framework of the GINOP-2.3.4-15-2016-00004 project, which is aimed at promoting cooperation between higher education and industry. Special thanks to 3D Lab at the University of Miskolc for the electron microscopic images.

Conflicts of Interest: On behalf of all authors, the corresponding author states that there is no conflict of interest.

\section{References}

1. Ren, C.; Yang, P.; Gao, J.; Huo, X.; Min, X.; Bi, E.Y.; Liu, Y.; Wang, Y.; Zhu, M.; Liu, J. Catalytic reduction of aqueous chlorate with $\mathrm{MoO}_{\mathrm{x}}$ immobilized on Pd/C. ACS Catal. 2020, 10, 8201-8211. [CrossRef]

2. WHO. Chlorite and chlorate in drinking-water. In Guidelines for Drinking-Water Quality; World Health Organization (WHO): Geneva, Switzerland, 2005; p. 31.

3. Brinkmann, T.; Giner Santonja, G.; Schorcht, F.; Roudier, S.; Delgado Sancho, L. Best Available Techniques Reference Document for the Production of Chlor-alkali; Jrc Science and Policy Reports: Luxembourg, 2014. [CrossRef]

4. Jakab-Nácsa, A.; Stomp, D.; Farkas, L.; Kaptay, G. Large NaCl-effect on the decomposition rate of chlorate ions in HCl-containing brine solutions and its consequences for the chlor-alkali industry. Period. Polytech. Chem. Eng. 2020, 65, 238-242. [CrossRef]

5. Rohonczy, J. Szervetlen Kémia, I. Az s-és p-Mezö Elemeinek Kémiája Egyetemi Jegyzet; Eötvös Lóránd Tudományegyetem TTK: Budapest, Hungary, 2017; ISBN 9788632848532.

6. Chlorine. Available online: http:/ / www.essentialchemicalindustry.org/chemicals/chlorine.html (accessed on 26 November 2019 ).

7. Maslamani, N.; Khan, S.B.; Danish, E.Y.; Bakhsh, E.M.; Zakeeruddin, S.M.; Asiri, A.M. Carboxymethyl cellulose nanocomposite beads as super-efficient catalyst for the catalytic reduction of organic and inorganic pollutants. Int. J. Biol. Macromol. 2020, 167, 101-116. [CrossRef]

8. Bergner, D.; Hartmann, M. Chlorate and oxygen formation in alkali chloride membrane electrolysis. J. Appl. Electrochem. 1993, 23, 103-107. [CrossRef]

9. Millet, P. Chlor-alkali technology: Fundamentals, processes and materials for diaphragms and membranes. In Handbook of Membrane Reactors; Woodhead Publishing: Sawston, UK, 2013; Volume 2, pp. 384-415, ISBN 9780857097347.

10. Whiting, G.T.; Chung, S.H.; Stosic, D.; Chowdhury, A.D.; Van Der Wal, L.I.; Fu, D.; Zecevic, J.; Travert, A.; Houben, K.; Baldus, M.; et al. Multiscale mechanistic insights of shaped catalyst body formulations and their impact on catalytic properties. ACS Catal. 2019, 9, 4792-4803. [CrossRef]

11. Moon, D.H.; Chung, W.J.; Chang, S.W.; Lee, S.M.; Kim, S.S.; Jeung, J.H.; Ro, Y.H.; Ahn, J.Y.; Guo, W.; Ngo, H.H.; et al. Fabrication and characterization of Ni-Ce-Zr ternary disk-shaped catalyst and its application for low-temperature $\mathrm{CO}_{2}$ methanation. Fuel 2020, 260, 116260. [CrossRef]

12. Sevilla, M.; Fuertes, A.B. Graphitic carbon nanostructures from cellulose. Chem. Phys. Lett. 2010, 490, 63-68. [CrossRef]

13. Habibi, Y.; Lucia, L.A.; Rojas, O.J. Cellulose nanocrystals: Chemistry, self-assembly, and applications. Chem. Rev. 2010, 110, 3479-3500. [CrossRef] 
14. Cheng, F.; Zhang, X.; Yang, X.; Li, R.; Wu, Y. Research on carbonization kinetic of cellulose-based materials and its application. J. Anal. Appl. Pyrolysis 2021, 158, 105232. [CrossRef]

15. Zhou, W.; Jiang, C.; Duan, X.; Song, J.; Yuan, Y.; Chen, N. Fe3O4/carbonized cellulose micro-nano hybrid for high-performance microwave absorber. Carbohydr. Polym. 2020, 245, 116531. [CrossRef]

16. Hwang, H.-C.; Woo, J.S.; Park, S.-Y. Flexible carbonized cellulose/single-walled carbon nanotube films with high conductivity. Carbohydr. Polym. 2018, 196, 168-175. [CrossRef] [PubMed]

17. Huang, Y.; Lin, Z.; Zheng, M.; Wang, T.; Yang, J.; Yuan, F.; Lu, X.; Liu, L.; Sun, D. Amorphous $\mathrm{Fe}_{2} \mathrm{O}_{3}$ nanoshells coated on carbonized bacterial cellulose nanofibers as a flexible anode for high-performance lithium ion batteries. J. Power Sources 2016, 307, 649-656. [CrossRef]

18. Prekob, A.; Hajdu, V.; Muránszky, G.; Fiser, B.; Sycheva, A.; Ferenczi, T.; Viskolcz, B.; Vanyorek, L. Application of carbonized cellulose-based catalyst in nitrobenzene hydrogenation. Mater. Today Chem. 2020, 17, 100337. [CrossRef]

19. Chen, X.; Huo, X.; Liu, J.; Wang, Y.; Werth, C.J.; Strathmann, T.J. Exploring beyond palladium: Catalytic reduction of aqueous oxyanion pollutants with alternative platinum group metals and new mechanistic implications. Chem. Eng. J. 2017, 313, 745-752. [CrossRef]

20. Kuznetsova, L.I.; Kuznetsova, N.I.; Koscheev, S.V.; Zaikovskii, V.I.; Lisitsyn, A.S.; Kaprielova, K.M.; Kirillova, N.V.; Twardowski, Z. Carbon-supported iridium catalyst for reduction of chlorate ions with hydrogen in concentrated solutions of sodium chloride. Appl. Catal. A Gen. 2012, 427-428, 8-15. [CrossRef]

21. Rutger, V.S.; Klesing, A.; Neuenfeldt, G.; Ottmann, A. Method for Removing Chlorate Ions from Solutions. U.S. Patent 6,270,682, 7 August 2001.

22. Kim, H.S.; Kim, T.W.; Koh, H.L.; Lee, S.H.; Min, B.R. Complete benzene oxidation over Pt-Pd bimental catalyst supported on $\gamma$-alumina: Influence of Pt-Pd ratio on the catalytic activity. Appl. Catal. A Gen. 2005, 280, 125-131. [CrossRef]

23. Kim, G.J.; Shin, J.H.; Hong, S.C. Study on the role of $\mathrm{Pt}$ and $\mathrm{Pd}$ in $\mathrm{Pt}-\mathrm{Pd} / \mathrm{TiO}_{2}$ bimetallic catalyst for $\mathrm{H}_{2}$ oxidation at room temperature. Int. J. Hydrog. Energy 2020, 45, 17276-17286. [CrossRef]

24. Saxena, R.; De, M. Enhanced performance of supported Pd-Pt bimetallic catalysts prepared by modified electroless deposition for butane dehydrogenation. Appl. Catal. A Gen. 2021, 610, 117933. [CrossRef]

25. Persson, K.; Ersson, A.; Colussi, S.; Trovarelli, A.; Järås, S.G. Catalytic combustion of methane over bimetallic Pd-Pt catalysts: The influence of support materials. Appl. Catal. B Environ. 2006, 66, 175-185. [CrossRef]

26. Niquille-Röthlisberger, A.; Prins, R. Hydrodesulfurization of 4,6-dimethyldibenzothiophene and dibenzothiophene over aluminasupported Pt, Pd, and Pt-Pd catalysts. J. Catal. 2006, 242, 207-216. [CrossRef]

27. Martínez Guerrero, R.; Hernández-Gordillo, A.; Santes, V.; Vargas García, J.R.; Escobar, J.; Díaz-García, L.; Díaz Barriga Arceo, L.; Garibay Febles, V. Monometallic Pd and Pt and bimetallic Pd-Pt/ $\mathrm{Al}_{2} \mathrm{O}_{3}-\mathrm{TiO}_{2}$ for the HDS of DBT: Effect of the Pd and Pt incorporation method. J. Chem. 2014, 1, 1-10. [CrossRef]

28. Matsubayashi, N.; Yasuda, H.; Imamura, M.; Yoshimura, Y. EXAFS study on Pd-Pt catalyst supported on USY zeolite. Catal. Today 1998, 45, 375-380. [CrossRef]

29. Byun, S.; Song, Y.; Kim, B.M.; Kim, B.M. Heterogenized bimetallic Pd-Pt-Fe $\mathrm{O}_{4}$ nanoflakes as extremely robust, magnetically recyclable catalysts for chemoselective nitroarene reduction. ACS Appl. Mater. Interfaces 2016, 8, 14637-14647. [CrossRef]

30. Micheaud-Especel, C.; Bazin, D.; Guérin, M.; Marécot, P.; Barbier, J. Study of supported bimetallic Pd-Pt catalysts. Characterization and catalytic activity for toluene hydrogenation. React. Kinet. Catal. Lett. 2000, 69, 209-216. [CrossRef]

31. Lei, Y.L.; Lin, D.Q.; Yao, S.J.; Zhu, Z.Q. Preparation and characterization of titanium oxide-densified cellulose beads for expanded bed adsorption. J. Appl. Polym. Sci. 2003, 90, 2848-2854. [CrossRef]

32. Sikora, E.; Katona, K.K.; Muránszky, G.; Bánhidi, O.; Kristály, F.; Szabó, J.T.; Windisch, M.; Fiser, B.; Vanyorek, L. Cellulose-based catalyst design for efficient chlorate reduction. Arab. J. Chem. 2021, 14, 103202. [CrossRef] 